\title{
HEPATITIS IN THE BRAZILIAN AMAZON: A LITERATURE REVIEW
}

\section{Hepatite na Amazônia Legal: Uma revisão de literatura}

\author{
So Yon Jun \\ Department of Environmental Health, Harvard University. \\ soyonjun@hsph.harvard.edu \\ Tatiana Schor \\ Department of Geography, Universidade Federal do Amazonas. \\ tschor@ufam.edu.br
}

\begin{abstract}
This paper examines the prevalence of hepatitis in the Brazilian Amazon and efforts to reduce the spread of the disease. Widespread hepatitis in areas along the Amazon continues to be a source of concern for Brazilian public health officials as it suggests low levels of sanitation and overall awareness of the disease. It is often difficult to obtain health data in the Brazilian Amazon because of the difficulty of accessing and assessing threat in these areas. A bibliometric review of hepatitis in the Brazilian Amazon reveals a paucity of data and research on the issue. As changes in the environment and climate will most likely lead to an increased disease burden amongst both rural and urban populations, there is a need for a comprehensive study on dynamics of hepatitis infection amongst Brazilians living in the Amazon region. Public health officials and government agencies must work together to obtain longitudinal data on hepatitis transmission.
\end{abstract}

Keywords: hepatitis, Brazilian Amazon, public health

RESUMO: Este artigo examina a prevalência da hepatite na Amazônia brasileira e os esforços para reduzir a disseminação da doença. A hepatite disseminada em áreas ao longo da Amazônia continua sendo uma fonte de preocupação para as autoridades de saúde pública brasileiras, uma vez que sugere baixos níveis de saneamento e consciência geral da doença. Muitas vezes, é difícil obter dados de saúde na Amazônia brasileira devido à dificuldade de acessar e avaliar ameaças nessas áreas. Uma revisão bibliométrica da hepatite na Amazônia brasileira revela uma escassez de dados e pesquisas sobre $o$ assunto. Como as mudanças no ambiente e no clima provavelmente levarão a um aumento da carga de doenças entre as populações rurais e urbanas, há a necessidade de um estudo abrangente sobre a dinâmica da infecção por hepatite entre os brasileiros que vivem na região amazônica. Agentes de saúde pública e agências governamentais devem trabalhar juntos para obter dados longitudinais sobre a transmissão de hepatite.

Palavras-Chave: hepatite, Amazônia brasileira, saúde pública 
HEPATITIS IN THE BRAZILIAN AMAZON:

A LITERATURE REVIEW

\section{INTRODUCTION}

Hepatitis is a global health concern, impacting populations across the global, but has been largely ignored until recent years. Viral hepatitis impacts 400 million individuals globally and 1.4 million people die each year from the disease (WHO). In 2015, over 114 million reported having Hepatitis $A$ and 343 million people reported having chronic hepatitis B (GBD 2015). While hepatitis is prevalent worldwide, various local factors such as sanitation condition can influence the frequency of transmission. In the past two decades, hepatitis has emerged as a public health concern in the Brazilian Amazon with an increase in reported incidences of hepatitis. Hepatitis is a concern for Brazilian health officials as it is easily transmitted by fecal contamination, sexual encounters, and blood. Because local sanitation and education can play a large role in reducing transmission, hepatitis needs to be understood from a social dimension and not just from an epidemiological perspective. In order to combat hepatitis in the Brazilian Amazon, public health officials as well as doctors must find innovative means to work at a municipal level to improve sanitation.

The Brazilian Amazon, or Amazônia Legal, encompasses nine states: Acre, Amapá, Amazonas, Pará, Rondônia, Roraima, Tocantins, Mato Grosso, and Maranhão (Figure 1). The Brazilian Amazon covers around 5 million $\mathrm{km}^{2}$ and also encompasses the largest preserved tropical rain forest in the world (Amaral et al. 2006). It is also home to innumerable endemic flora and fauna and contributes heavily to the world biodiversity. In the recent decades, the region has also become a space for economic development with the expansion of urbanization and extraction industries. Despite the rapid rates of deforestation and human occupation in the Brazilian Amazon, there are relatively few researchers examining the human dimension of the changes in the region (Amaral et al. 2006). Unlike general expectations that urbanization improves sustainability, studies suggest that growth in urban population has not improved the quality of life of local populations due to the low health, education, and income (Becker 1995). The problem of sanitation is not just a public health concern but an environmental problem for the ecosystem in the region as well (Becker 2001). Rapid urbanization and settlement in the Brazilian Amazon has been unmanaged and unregulated at times, leading to poor sanitation infrastructure. Magalhães and Rojas (2007) note that dramatic urbanization in the region has led to informal settlements without proper land use planning or social welfare programs. These informal settlements are also often located in areas vulnerable to dangers such as flooding. Drainage infrastructure are thus poor and lacking, leaving raw sewage and garbage to be thrown directly onto the land and rivers. According to Trata Brasil, a Brazilian NGO focused on sanitation, only $50 \%$ of Brazil's population has access to sewage collection which means more than 100 million Brazilians do not have access to the service. Trata Brasil also reports that people in the Brazilian Amazon suffer from diseases related to the lack of basic sanitation. Furthermore, many settlements are located close to the river, leading to frequent flooding that often spreads trash refuge and even diseases such as hepatitis $A$. 


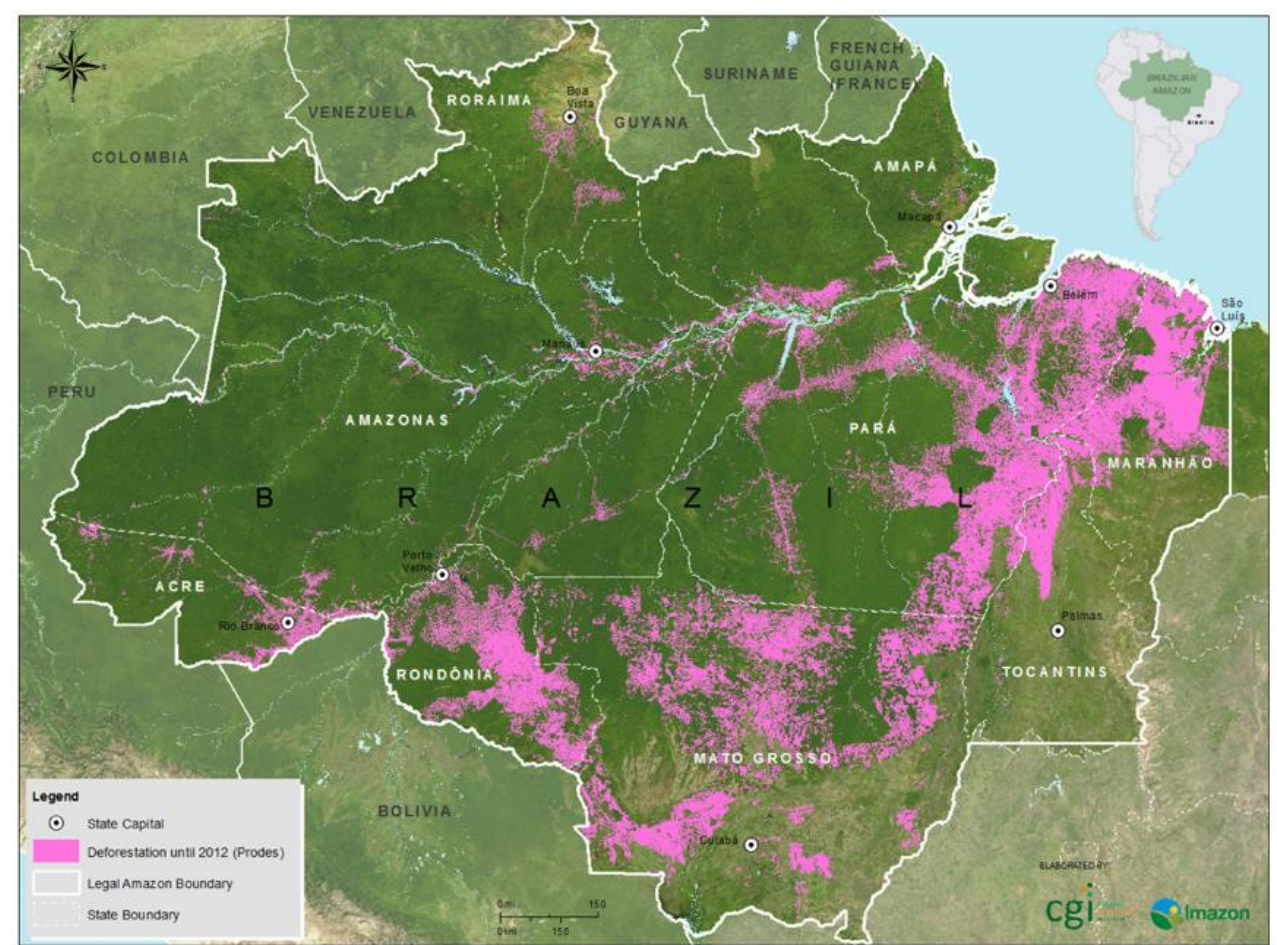

Figure 1. Map of Brazilian Amazon (Instituto do Homem e Meio Ambiente da Amazônia)

Hepatitis is a virally induced inflammation of the liver and can be both acute or chronic. There are five different types of Hepatitis viruses from A (HAV), B (HBV), C (HCV), D (HDV), and $E(H E V)$. A number of new hepatitis viruses such as G or GBV-C were discovered in the late 1990s but it is unclear as to whether they are truly hepatotropic (Pessoa et al. 1998; Reshetnyak et al. 2008). Vaccination can prevent HAV and HBV but currently there are no vaccines for HCV, HDV, and HEV (CDC 2017). For many people who have contracted the virus, hepatitis can be asymptomatic as the disease can be both acute or chronic. For those who develop chronic hepatitis, symptoms such as jaundice may occur and if left untreated, hepatitis can develop into liver cancer. Although hepatitis can be cured on its own, if the virus doesn't clear itself it will lead to chronic liver failure and liver cancer. According to the World Health Organization (WHO), viral hepatitis is not being properly addressed globally since the disease is often difficult to detect (WHO 2017). WHO also estimates that death from viral hepatitis will rise in the future.

Many countries like the United States list hepatitis as a health concern for international travelers. In particular, contraction of HAV and HBV are risk factors for travelers to Brazil (CDC 2017). The Center for Disease Control (CDC) notes that in Brazil, HAV can be contracted through food and water consumption resulting in fecal and oral contamination. HBV can be contracted through sexual contact and needle as well as blood contamination (CDC 2017). While HCV is not listed as a threat on the CDC website, there is a disease burden from HCV in Brazil because there are no vaccines 
for the disease. In Brazil, about 1.5 million people have become chronically infected with HCV (Kretzer et al. 2014). While hepatitis is of great health concern in Brazil, there is much research that must be done as well as public health policy implementations. For instance, Saúde e Sociedade, an interdisciplinary journal that aims to disseminate the knowledge of health practices, only lists one article related to hepatitis, suggesting a lack of research on hepatitis (Figure 2). Disease burden in developing regions such as the Brazilian Amazon are impacted by environmental factors such as climate, biodemography and migration, or land use change (Bauch et al. 2014). Immigrant communities for instance have been shown to have higher HCV in the southern Brazilian Amazon (Souto et al. 1999). There also appears to be differences in hepatitis occurrence within the Amazon region. According to Viana et al. (2005), hepatitis D has largely been limited to the western Amazon region where HBV and HDV are thought to lead to co-infection. It is possible that HBV and HDV have spread to other regions since 2005 but there is a lack of data available. Furthermore, one study found HBV and HCV to be endemic in the city of Buriticupu, Maranhão (Khouri et al. 2010). Overall, there appears to be a lack of data available on the infection rates of hepatitis throughout the Brazilian Amazon. This may be due to the aforementioned issue of lack of research in the area. For instance, the first comprehensive health survey of indigenous people's health and nutrition in Brazil was only conducted in 2008 to 2009 (Coimbra et al. 2013).

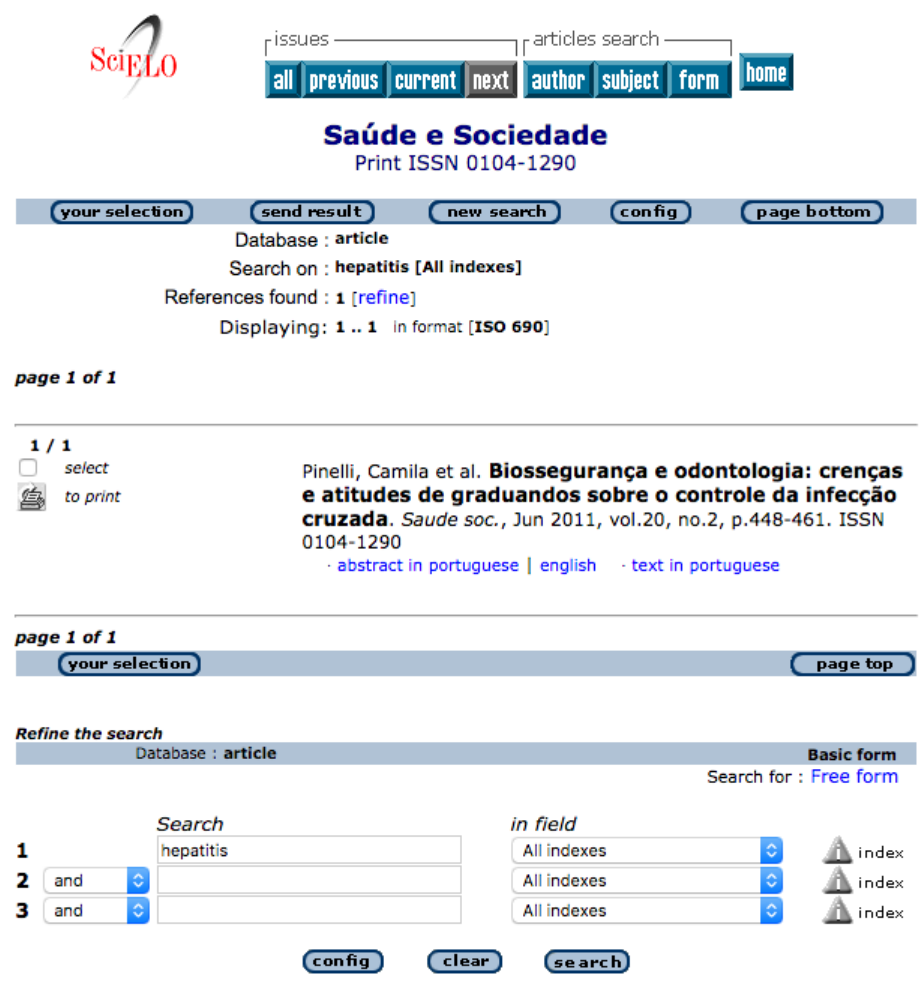

Figure 2. Screenshot of search results for keyword hepatitis in Saúde e Sociedade on SciELO Brasil 
Hepatitis is also of great concern as there are indications that contracting hepatitis may lead to easier co-infection of Malaria and other zoonotic diseases (Andrade et al. 2011). Another health concern linked to co-infection is the Lábrea Black Fever, also known as Lábrea Hepatitis. Lábrea Black Fever is an unusual type of hepatitis found in the Amazon Basin which is thought to occur through the co-infection of HDV and HBV; the disease is characterized by rapid liver failure (Fonseca et al. 1992). It is crucial that a database for hepatitis is created for the Brazilian Amazon region to assess disease risk and help create policy measures to reduce risk. Research on the disease should also be augmented by social research examining each region's sanitation and poverty levels.

\section{METHODS}

To survey the existing literature on the topic of hepatitis in the Brazilian Amazon, online databases for peer-reviewed literature were used to conduct a bibliometric survey. Using the SciELO Brasil (http://www.scielo.br/), an electronic library for Brazilian scientific journals, an attempt to survey the number of research that has been done on the topic of Hepatitis in Brazil. On SciELO Brasil, the abstracts of scientific journals are made available in both Portuguese and English. Using SciELO Brasil's search index, three separate searches were done. The first search was to compare the amount of hepatitis research being done in the Pan-Amazonia area in comparison to the Brazilian Amazon. The first search category entailed searching for keywords 'hepatitis' and 'amazon' in the SciELO Brasil website's subject search form. The second search category consisted of keywords 'hepatitis,' 'brazil,' and 'amazon' in the titles of the articles. A SciELO Brasil search was done for the second category by replacing the keyword "brazil" with "brasil" to check if there were any differences in the search results based on spelling. The third search category used the keywords 'hepatitis' and 'brazil' in the title and 'amazon in the abstract (Table 1).

Table 1. List of search categories used in the study along with the corresponding key words and database utilized for each category.

\begin{tabular}{lll}
\hline Category & Keywords & Database Used \\
First & 'hepatitis' and 'amazon' in title & SciELO Brasil \\
Second & 'hepatitis' 'amazon' and 'brazil' in title & $\begin{array}{l}\text { SciELO Brasil, Clarivate Web of } \\
\text { Science, PubMed, PMC, CLIO }\end{array}$ \\
Third & 'hepatitis' 'amazon' in title and 'brazil' in $\begin{array}{l}\text { SciELO Brasil, Clarivate Web of } \\
\text { Science, PubMed, PMC }\end{array}$
\end{tabular}

Organized by authors

Because SciELO Brasil lists Brazilian journals, a literature search was also conducted using the Clarivate Web of Science, PubMed (https://www.ncbi.nlm.nih.gov/pubmed), PubMed Central (PMC) (https://www.ncbi.nlm.nih.gov/pmc/), and the CLIO Columbia 
University Catalog (https://clio.columbia.edu/) databases to survey global scholarship on the topic. In these databases, the second and third search category used on the SciELO Brasil database was applied. The third search category was used on all databases excluding CLIO because it did not provide an option to search for abstract keywords. On each individual database, articles that pertained to the topic of hepatitis in the Brazilian Amazon were searched.

\section{RESULTS}

The results for the bibliographic review with three keywords ('hepatitis,' 'brazil,' and 'amazon') in the title did not suggest wide scholarship on hepatitis in the Brazilian Amazon. The first category search done for journals with the keywords 'hepatitis' and 'amazon' in their title within the SciELO Brasil database yielded a total of 37 unique references. A first category search with the keyword 'brasil' instead of 'brazil' did not result in any new articles but resulted in only 6 results that all appeared in the first category search. A second category search done for journals with the keywords 'hepatitis,' 'brazil,' and 'amazon' in their title in SciELO Brasil only yielded 6 references. Comparing the results from the two searches, it was found that the search results from the first search category incorporated results from the second search category. A cross examination of the results from the first and second search category yielded a total of 37 unique articles. The search for keywords 'hepatitis' and 'amazon' in the title with 'brazil' in the abstract yielded a higher number of articles. A search on SciELO Brasil led to 15 references. There were 4 unique articles that were not found during the first and second category search, resulting in a total of 41 articles related to hepatitis on SciELO Brasil (Table 2).

A literature search using the secondary search category yieled 11 unique results for $P M C$ and 19 unique results for CLIO database. A search on PubMed using the second search category yielded 12 articles keywords 'hepatitis,' 'brazil,' and 'amazon' in their title. Web of Science yielded 14 individual articles for the second search category with 1 repetition, leaving 13 articles. A cross examination of the four databases yielded a total of 27 unique articles; among the 27 articles, 6 appeared in the SciELO Brasil database. In total, 21 unique articles were found that were not listed in SciELO Brasil (Table 3). 
Table 2. List of 41 unique articles by author, article title, and year found on SciELO Brasil using the three search categories.

Author

Pereira, F.E.L., et al.

Santos, A. K. C. R et al.

Pinho, J.R.R. et al.

Souto, F.J.D., et al.

Ferrari, J.O. et al.

Souto, F.J.D., et al.

Braga, W.S.M., et al.

de Paula, V.S., et al.

Souto, F.J.D., et al.

Simonetti, S.R.R., et al.

Echevarría, José $M$. and León, Pilar

Bensabath, Gilberta and Soares, Manoe do Carmo Pereira

Braga, Wornei Silva Miranda

Conde, Simone

Regina Souza da Silva et al.

Fonseca, José Carlos Ferraz da and Brasil, Leila Melo

Fonseca, José Carlos Ferraz da.

Miranda, Esther Castello Branco

Mello et al.

Monteiro, Maria Rita de Cassia Costa et al.

Nunes, Heloisa Marceliano, Soares M.C.P, et al.

Souto, Francisco José Dutra.

Tavares-Neto, J. et al.

Braga, Wornei Silva Miranda et al.

\section{Article Title}

Year

Labrea-like hepatitis in Vitoria, Espirito Santo state, Brazil: report of a case.

A possible correlation between the host genetic background in the epidemiology of Hepatitis $B$ virus in the Amazon region of Brazil.

Hepatitis $G$ virus / GB virus $C$ in Brazil. Preliminary report.

Concomitant high prevalence of Hepatitis $\mathrm{C}$ virus antibodies and Hepatitis $B$ virus markers in a small village fo the Amazon Region, Mato Grosso State, Brazil.

The seroprevalence of hepatitis $B$ and $C$ in an Amerindian population in the southwestern Brazilian Amazon

Hepatitis C virus prevalence among an immigrant community to the Southern Amazon, Brazil.

Ocorrência da infecção pelo vírus da hepatite B (VHB) e delta (VHD) em sete grupos indígenas do Estado do Amazonas.

Seroprevalence of viral hepatitis in riverine communities from the Western Region of the Brazilian Amazon Basin.

Prevalence of hepatitis $B$ and $C$ virus markers among malaria-exposed gold miners in Brazilian Amazon.

Detection of Hepatitis B Virus Antigens in Paraffin-embedded Liver Specimens from the Amazon Region, Brazil.

Epidemiology of viruses causing chronic hepatitis among populations from the Amazon Basin and related ecosystems.

A evolução do conhecimento sobre as hepatites virais na região amazônica: da epidemiologia e etiologia à prevenção

Infecção pelos vírus das hepatites B e D entre grupos indígenas da Amazônia Brasileira: aspectos epidemiológicos.

Prevalência de genótipos e de mutantes pré-core A-1896 do vírus da hepatite B e suas implicações na hepatite crônica, em uma população da Amazônia oriental.

Infecção pelo vírus da hepatite $\mathrm{C}$ na região Amazônica brasileira.

1993

1995

1996

1996

1999

1999

2001

2001

2001

2002

2003

2004

2004

2004

2004

Hepatite fulminante na Amazônia brasileira

2004

Infecções pelos vírus das hepatites B e C e o carcinoma hepatocelular na Amazônia oriental.

Hepatite C: prevalência e fatores de risco entre portadores do VIH/SIDA em Belém, Pará, na Amazônia brasileira.

Infecção pelo vírus da hepatite A em área indígena da Amazônia oriental brasileira.

A hepatite B e os movimentos migratórios no Estado de Mato Grosso, Brasil.

Seroprevalence of hepatitis B and C in the Western Brazilian Amazon region (Rio Branco, Acre): a pilot study carried out during a hepatitis $B$ vaccination program.

Soroprevalência da infecção pelo vírus da hepatite B e pelo plasmódio em Lábrea, Amazonas: estimativa da ocorrência de prováveis coinfecções. 
El Khouri, Marcelo et al.

Braga, Wornei Silva Miranda et al.

Gomes, Irenio et al.

Barros Júnior, Gildo Maia et al.

Braga, Wornei Silva Miranda et al.

El Khouri, Marcelo et al.

de Oliveira, Claudia Suellen Ferro de et al.

Sawada, Leila et al.

Braga, Wornei Silva Miranda et al.

Dias, Ádila Liliane Barros et al.

Amaral, Ivanete do Socorro Abraçado et al.

Amaral, Ivanete do Socorro Abraçado et al.

Vieira, Gabriel de Deus et al.

Santos, Kemper Nunes dos et al.

Spitz, Natália, Mello, Francisco CA and Araujo, Natalia Motta

Vieira, Gabriel de Deus, et al.

Souto, Francisco José Dutra.

Tarragô, A.M., et al.
Seroprevalence of hepatitis B virus and hepatitis C virus in Monte Negro in the Brazilian western Amazon region.

Low prevalence of hepatitis $B$ virus, hepatitis $D$ virus and hepatitis $C$ virus among patients with human immunodeficiency virus or acquired immunodeficiency syndrome in the Brazilian Amazon basin.

Peripheral neuropathy in patients with hepatitis virus $\mathrm{C}$ infection in the Amazon region.

Hepatite crônica B oculta: prevalência e aspectos clínicos em população de elevada endemicidade de infecção pelo vírus da hepatite $B$ na Amazônia Ocidental Brasileira

Prevalence of hepatitis A virus infection: the paradoxical example of isolated communities in the western Brazilian Amazon region.

Endemic hepatitis $b$ and $c$ virus infection in a brazilian eastern amazon region.

Hepatitis $B$ and $C$ virus infection among Brazilian Amazon riparians.

2005

2006

2006

2008

2009

2010

2011

Distribution of hepatitis C virus genotypes among different exposure categories in the State of Pará, Brazilian Amazon.

Hepatitis D virus infection in the Western Brazilian Amazon - far from a vanishing disease.

Molecular characterization of the hepatitis B virus in autochthonous and endogenous populations in the Western Brazilian Amazon.

Evaluation of the therapeutic response of hepatitis $\mathrm{C}$ in coinfected patients (HIV/HCV): a study of cases from a hospital for chronic liver diseases in the Eastern Brazilian Amazon

Assessment of the treatment of chronic hepatitis $C$ virus infection: a case series from a hospital in the Brazilian Amazon region.

OCCURRENCE AND SPATIAL DISTRIBUTION OF HEPATITIS C IN A WESTERN BRAZILIAN AMAZON STATE.

ANALYSIS OF POLYMORPHISMS IN THE INTERLEUKIN 18 GENE PROMOTOR (-137 G/C AND -607 C/A) IN PATIENTS INFECTED WITH HEPATITIS C VIRUS FROM THE BRAZILIAN AMAZON.

Full-genome sequences of hepatitis $B$ virus subgenotype D3 isolates from the Brazilian Amazon Region.

HEPATITIS B IN RONDÔNIA (WESTERN AMAZON REGION, BRAZIL): descriptive analysis and spatial distribution.

Distribution of hepatitis B infection in Brazil: the epidemiological situation at the beginning of the 21 st century

Sofosbuvir and daclatasvir combination therapy for current hepatitis $\mathrm{C}$ virus genotype 4 achieves SVR: a case report of HCV genotype 4 from the Amazon.

Organized by authors

For the third search category, PubMed yielded 33 results instead of only 12 . Out of the 33 PubMed results, only 8 were articles were not found in searches using the first and second category. There were only 2 articles found for $P M C$ and they were both found through the second category search. There were 35 results for Web of Science and 2 results did not include the keyword "brazil" in the abstract, leaving 33 results. Only 4 
HEPATITIS IN THE BRAZILIAN AMAZON:

A LITERATURE REVIEW

articles from Web of Science search were found exclusively from through the third category search. From PubMed, PMC, and Web of Science, a total of 12 unique articles were found (Table 4). In total, cross examining the references from the first, second, and third search category for all five databases resulted in a total of 74 unique articles.

Table 3. All 21 unique articles found on PMC, CLIO, PubMed and Clarivate Web of Science, excluding results found through SciELO Brasil. Yellow represents results from the second category on PMC. There were no results found exclusively through the PubMed or Web of Science second search category searches. Pink represents CLIO second search category. Grey represents results found on multiple databases.

\section{Author}

Bensabath, G., et al.

Strauss, et al.

Juarez, E., et al.

Botelho, R., et al.

Fonseca, J. C. F., et

al.

Miranda, E. C., et al.

Demachki, S., et al.

Torres, K.L., et al.

Andrade, B.B., et al.

Leao, J., et al.

da Costa Castilho,

M., et al.

Nascimento,

A.C.M., et al.

Cicero, M., et al.

Botelho-Souza, L.

F., et al

Crispim, M. A., et al.

da Silva Conde,

S.R.S., et al.

Botelho-Souza, L.

F., et al

Choconta-

Piraquive, L.A., et al.

\section{Article Title}

\section{Amazon Basin}

Unexpected low prevalence of delta antibodies in the east Amazon region and São Paulo: evidence for regional differences in the epidemiology of delta hepatitis virus within Brazil

Hepatitis B and delta vaccination program in the western Amazon region of Brazil.

The Absence of Escape Mutant of Hepatitis-B Virus (Hbv) in Immunized Children in the Amazon Basin, Brazil - Final Report.

Chronic hepatitis C in the Western Amazon region, Brazil.

[Hepatitis B and C virus infection and the hepatocellular carcinoma in the East Amazon, Brazil].

Morphologic study of chronic hepatitis $\mathrm{C}$ in oriental Amazon region (Brazil) focusing on stellate hepatic cells and extracellular matrix using confocal microscopy.

CHARACTERIZATION OF HEPATITIS C VIRUS INFECTION IN AMAZON BLOOD DONORS, BRAZIL

Hepatitis B Infection Is Associated with Asymptomatic Malaria in the Brazilian Amazon

Non-invasive assessment of fibrosis using color Doppler ultrasound in patients with hepatitis $\mathrm{C}$ virus in the Amazon rainforest, Brazil.

Epidemiology and Molecular Characterization of Hepatitis B Virus Infection in Isolated Villages in the Western Brazilian Amazon

Nonalcoholic Fatty Liver Disease in Chronic Hepatitis B and C Patients from Western Amazon

Full length genome characterization of hepatitis delta virus in the Amazon region of Brazil, using dried-blood samples collection.

Development of a reverse transcription quantitative real-time PCR-based system for rapid detection and quantitation of hepatitis delta virus in the western Amazon region of Brazil.

Molecular epidemiology of hepatitis B and hepatitis delta viruses circulating in the Western Amazon region, North Brazil.

Absence of Correlation between IL-28B Gene Polymorphisms and the Clinical Presentation of Chronic Hepatitis B in an Amazon Brazilian Population

Characterization of the Genotypic Profile of Hepatitis Delta Virus: Isolation of HDV Genotype-1 in the Western Amazon Region of Brazil.

Compliance with birth dose of Hepatitis $B$ vaccine in high endemic and hard to reach areas in the Colombian amazon: results from a vaccination survey 
Cunha, B.A., et al. dos Moresco M.N., et al.

Quizhpe, E., et al.
Fever in a traveler returning from the Amazon. Do not forget hepatitis A

Occult hepatitis $B$ virus infection among blood donors from the Brazilian

2016

Amazon: implications for transfusion policy

Five-Year Eradication of Hepatitis B Infection after an Outreach Immunization Program in the Waorani Population in the Ecuadorian Amazon
2016

2016

Organized by authors

Table 4. All 12 unique articles found on PMC, PubMed and Clarivate Web of Science, excluding results found on SciELO Brasil. Green represents results of third search category only found on PubMed. There were no new articles found for the third category on PMC. Blue represents the third search category results only found through Web of Science.

\begin{tabular}{|c|c|c|}
\hline Author & Article Title & Year \\
\hline $\begin{array}{l}\text { Soares M.C.P., et } \\
\text { al. }\end{array}$ & $\begin{array}{l}\text { EAST AMAZON REGION INDIANS AS RISK POPULATION FOR } \\
\text { HEPATITIS-D (DELTA) }\end{array}$ & 991 \\
\hline Soares M.C., et al. & $\begin{array}{l}\text { Epidemiology of hepatitis } \mathrm{B}, \mathrm{C} \text { and } \mathrm{D} \text { viruses among indigenous } \\
\text { Parakanã tribe in the Eastern Brazilian Amazon Region]. }\end{array}$ & 4 \\
\hline ang L., et a & Short report: hepatitis E infection in the Brazilian Amazon. & 5 \\
\hline-1 & $\begin{array}{l}\text { Hepatitis B virus infection in immigrants to the southern Brazilian } \\
\text { Amazon. }\end{array}$ & \\
\hline E.J., & Outbreak of hepatitis B virus in recent arrivals to the Brazilian Amazon & \\
\hline H.M., Soares & Hepatitis A virus infection in Amerindian area in the east Brazilian & 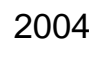 \\
\hline ., Silva H.M., & A & \\
\hline Braga W.s., et al. & $\begin{array}{l}\text { alaria infection in Lábrea, Brazilian } \\
\text { ction rates. }\end{array}$ & 5 \\
\hline De & zon Basin. & \\
\hline $\begin{array}{l}\text { Gouvêa } \\
\text { al. }\end{array}$ & $\begin{array}{l}\text { genotypes in chronically infected patients from } \\
\text { sin. }\end{array}$ & \\
\hline $\begin{array}{l}\text { Gomes-Gouvêa } \\
\text { M.S., et al. }\end{array}$ & $\begin{array}{l}\text { Hepatitis } B \text { virus and hepatitis delta virus genotypes in outbreaks of } \\
\text { fulminant hepatitis (Labrea black fever) in the western Brazilian Amazon } \\
\text { region. }\end{array}$ & 9 \\
\hline $\begin{array}{l}\text { de Oliveira M.S., et } \\
\text { al. }\end{array}$ & $\begin{array}{l}\text { Chronic hepatitis B and hepatitis D superinfection in patients in the } \\
\text { Brazilian Western Amazon }\end{array}$ & \\
\hline Silva, F.Q., & $\begin{array}{l}\text { Hepatitis C virus infection among illicit drug users in an archipelago of the } \\
\text { Amazon }\end{array}$ & 20 \\
\hline
\end{tabular}

Organized by authors

\section{DISCUSSION}

Overall, there is a need to improve understanding of hepatitis prevalence in the Brazilian Amazon. There are few longitudinal studies being conducted to understand how the disease spreads or if the distribution of the virus has changed over time. Most of the studies examined a particular hepatitis virus and their transmission dynamic or seroprevalence in a particular region, especially in the Western Brazilian Amazon. There were 19 total articles out of the 74 which focused on the Western Amazon alone (Table 2, 3, 4). Out of the 75 articles, 39 articles focused on HBV, 28 articles focused on HCV, 5 articles on HAV, 15 on HDV, and 1 on HEV. There was 1 article that focused 
HEPATITIS IN THE BRAZILIAN AMAZON:

A LITERATURE REVIEW

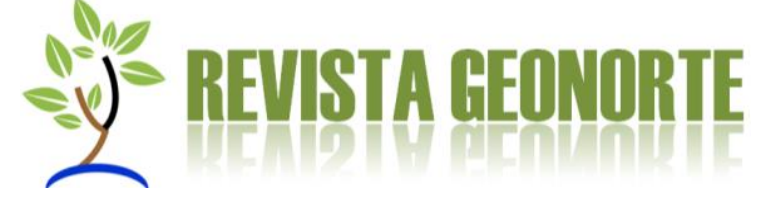

on HGV (Table 2). Several articles focused on more than one hepatitis virus but there no large-scale studies done of all hepatitis virus types throughout the region.

Many of the articles were written by the same authors. Wornei Silva Miranda Braga authored 8 articles. José Dutra Souto authored 7 articles. José Carlos Ferraz da Fonseca and Manoel do Carmo Pereira Soares authored 3 articles. Ivanete do Socorro Amaral, Marcelo El Khouri, Heloisa Marceliano Nunes, Luan Felipo Botelho-Souza, Viviane S de Paula, Michele Soares Gomes-Gouvêa, Simone Regina Souza da Silva Conde, Gilberta Bensabath, and Gabriel de Deus Vieira authored 2 articles each (Table 2, 3, 4). Furthermore, many studies focused a specific population such as adult males, hospital workers, immigrant, or riverine communities. There were no region wide hepatitis surveys throughout the legal Amazon. There is a need for studies which examine the social impacts and causes of hepatitis such as poverty, education level, sanitation, and access to healthcare. There is a need to understand the spatial distribution of hepatitis in the Amazon.

It is acknowledged that there are problems with limiting research to only five databases and three different search categories. It is likely that there are studies conducted in Amazonian countries besides Brazil that are not listed on SciELO Brasil. Moreover, different keywords may be attached to studies conducted within the legal Amazon. This study did not search for literature that focused on specific areas within the legal Amazon, such as the nine legal states. There are also numerous other peer-reviewed journals and non-peer reviewed databases that may contain hepatitis related research. However, methodologically, the five databases have a large scope and can provide a good insight into how much research has been done on the topic in the past few decades.

While hepatitis can be life threatening, its transmission can easily be prevented through vaccination. Preventative care can go a long way to reducing hepatitis risk in the region. Vaccination has proven to be effective for hepatitis A and $B$ (WHO 2016). Hepatitis $C$ can also be effectively cured as the WHO reports that over $90 \%$ of people with hepatitis $\mathrm{C}$ can be completely cured within 3-6 months. Furthermore, vaccination against HBV can protect individuals against HDV co-infection (Ponzetto et al. 1985). In places where both viruses are endemic like the Amazon Basin, vaccination may prove to be effective in reducing both HBV and HDV. While vaccines for HAV and HBV are readily available through the Brazilian National Immunization Program without cost, there is an overall lack of awareness for the need of vaccination (Mello 2013). HBV vaccination for instance, has increased among youth and children in the recent years but HBV cases has not decreased due to the lack of vaccination amongst adults (Passos et al. 2011).

The Brazilian Ministry of Health's current strategy for HCV is strengthening healthcare and surveillance as well as promoting universal access to medication (Kretzer et al. 2014). Providing mandatory vaccination for all types of hepatitis to people living in the Brazilian Amazon through use of floating clinics or at existing malaria clinics may help to alleviate the disease burden in the region. Floating hospitals or clinic can effectively provide medical services to remote areas in the Amazon. The Brazilian government has been working to create a "basic river health unit" system utilizing boats like the Igaraçu (Cedeno \& Coleman 2017). In particular, there is a pressing need to implement 
HEPATITIS IN THE BRAZILIAN AMAZON:

A LITERATURE REVIEW

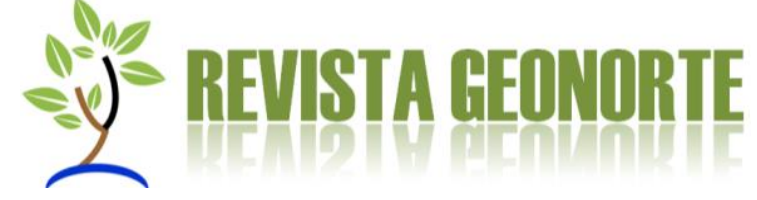

mandatory vaccination for HAV because of a decrease in the prevalence of antibody throughout the country which puts young children at higher risk for infection (Vital et al. 2008).

Sanitation and hygiene play an important role in preventing hepatitis transmission as individuals can become infected through contact with an infected person's fecal, oral, and blood (CDC 2017). Sanitation protocols must be regulated in urbanized areas with emphasis on both improving the sewer system and sterilization of medical tools in clinics. Brazil's sewage system is outdated and inefficient even in larger cities like Rio as fewer than half of households nationwide are hooked up to the main sewer lines (Barchfield 2015). Sanitation in isolated rural areas could be improved through constructing water treatment facilities and sustainable landfills. Acre Social and Economic Inclusion Project (PROACRE) has provided sanitation and basic public services access to hundreds of thousands of people in forest communities (World Bank 2014). Programs such as PROACRE need to be expanded to other regions in the Brazilian Amazon.

There is also a lack of education and awareness of hepatitis in the region, suggesting the need for wide spread educational measures; infectious diseases can be prevented if populations become more informed and literate (Ribeiro et al. 2014). There is an urgent need to educate communities on the importance of sanitation and to change waste production and water use behavior. In the Brazilian Amazon sanitation levels are low as there are often inadequate access of purified water. The lack of readily available proper water filtration leads individuals to choose potentially unsafe water sources such as handmade wells and water tanks which are vulnerable to contamination (Bicudo et al. 2010). For instance, the lack of access to clean water supplies have created a culture of 'caixa d'agua' in which households use water tanks to store water for long periods of time without proper sanitation (Osava 2016). Furthermore, improved sanitation can help reduce the risk of other diseases such as leptospirosis, malaria, zika, diarrhea, and more (Osava 2016).

Hepatitis must be regarded as a public health priority in the Brazilian Amazon. All five types of viral hepatitis have been found in the region and there are even new mutations of the disease as seen with the case of the Lábrea Black Fever. There is a need for a region-wide hepatitis prevalence study for each viral type. Prevalence studies can be useful in not only verifying the impact of existing prevention strategies but can also inform future control strategies (Kretzler et al. 2014). Future prevalence studies must be done across all ages and communities in order to assess the hepatitis disease burden in the Brazilian Amazon.

\section{CONCLUSION}

This bibliometric survey of existing research on hepatitis in the Brazilian Amazon underlines the need for further research on the subject. In particular, there is a need for more research that can inform scientific policy recommendations to reduce hepatitis prevalence and transmission in the region. Majority of the existing literature focuses on a particular strain of hepatitis or demographics and regions within Amazônia Legal. A broader regional survey on hepatitis throughout the 
HEPATITIS IN THE BRAZILIAN AMAZON:

A LITERATURE REVIEW

Brazilian Amazon is necessary to combat the impact the disease has on vulnerable populations.

\section{REFERENCES}

ANDRADE, B. B.; SANTOS, C. J.; CAMARGO, L. M.; SOUZA-NETO, S. M.; REISFILHO, A.; CLARÊNCIO, J.; BARRAL-NETTO, M. et al. Hepatitis B Infection Is Associated with Asymptomatic Malaria in the Brazilian Amazon. PLoS ONE, vol. 6(5), 2011.

BARCHFIELD, J. 'Medieval': Brazil's sewage system is comparable to London or Paris in the 14th century, 2015. from <http://www.businessinsider.com/medieval-brazilssewage-system-is-comparable-to-london-or-paris-in-the-14th-century-2015-9>,

Retrieved: April 11, 2017.

BAUCH, S. C.; BIREKNBACH, A. M.; PATTANAYAK, S. K.; SILLS, E. O. Public health impacts of ecosystem change in the Brazilian Amazon. Proceedings of the National Academy of Sciences, vol. 112(24), p. 7414-7419, 2015.

BECKER, B. K. Undoing myths: the Amazon-an urbanized forest. In Brazilian Perspectives on Sustainable Development of the Amazon Region. vol. 15 (eds. Clu"sener -Godt, M. and Sachs, I.) UNESCO. P. 53-89, 1995.

BECKER, B. K. Revisão das políticas de ocupação da Amazônia: é possível identificar modelos para projetar cenários?, 2001.

BICUDO, C. E. M., TUNDISI, J. G., SCHEUENSTUHL, M. C. B. Águas do Brasil: análises estratégicas. São Paulo: 2010. Rio de Janeiro: Academia Brasileira de Ciências. Instituto de Botânica, 2010.

CDC TRAVELERS' HEALTH. Health Information for Travelers to Brazil Traveler View, 2017. from <https://wwwnc.cdc.gov/travel/destinations/traveler/none/brazil>, Retrieved: March 23, 2017.

CEDENO, K.; COLEMAN, C. Perspective / This floating medical clinic offers a lifeline for the indigenous poor of the Amazon, 2017. from $<$ https://www.washingtonpost.com/news/in-sight/wp/2017/04/14/this-floating-medicalclinic-offers-a-lifeline-for-the-indigenous-poor-of-theamazon/?utm term=.a2f0833cd968>, Retrieved: May 05, 2017.

FONSECA, J. C.; FERREIRA, L. C.; BRASIL, L. M.; CASTINHO, M. D.; MOSS, R.; BARONE, M. Fulminant Labrea Hepatitis - the role of hepatitis A (HAV), B (HBV), C (HCV), and D (HDV) infection: preliminary report. Revista do Instituto de Medicina Tropical de São Paulo, vol. 34(6), p. 609-612, 1992. 
HEPATITIS IN THE BRAZILIAN AMAZON:

A LITERATURE REVIEW

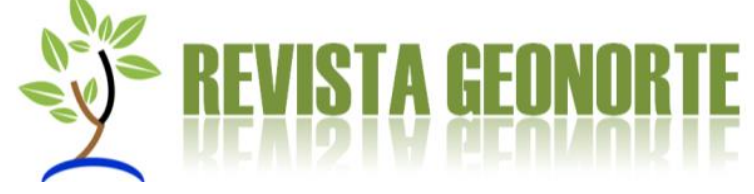

HANUS, J. S.; CERETTA, L. B.; SIMõES, P. W.; TUON, L. Incidence of hepatitis C in Brazil. Revista da Sociedade Brasileira de Medicina Tropical, vol. 48(6), p. 665-673, 2015.

CDC, Immunization Schedules, $2017 . \quad$ from $<$ https://www.cdc.gov/vaccines/schedules/hcp/imz/adult.html>, Retrieved: May 04, 2017.

KRETZER, I.F.; LIVRAMENTO, A.; CUNHA, J. et al. Hepatitis C Worldwide and in Brazil: Silent Epidemic-Data on Disease including Incidence, Transmission, Prevention, and Treatment, The Scientific World Journal, 2014.

MAGALHAES, F.; ROJAS, E. Facing the Challenges of Informal Settlements in Urban Centers: The Re-urbanization of Manaus, Brazil, 2007. from $<$ http://www.iadb.org/wmsfiles/products/publications/documents/1442373.pdf/>,

Retrieved: May 05, 2017.

MELLO, J. Vaccinations Required in Brazil, 2013. from $<$ http://thebrazilbusiness.com/article/vaccinations-required-in-brazil >, Retrieved: May 05, 2017.

OSAVA, M. Zika Epidemic Offers Sanitation a Chance in Brazil, 2016. from $<$ http://www.ipsnews.net/2016/02/zika-epidemic-offers-sanitation-a-chance-inbrazil/>, Retrieved: May 05, 2017.

PASSOS, A. M.; TREITINGER, A.; SPADA, C. Hepatitis B immunity and vaccination coverage among young adult males in the Air Force in South Brazil. Vaccine, vol. 29(49), p. 9284-9288, 2011.

PESSOA, M. G.; TERRAULT, N. A.; DETMER, J.; KOLBERG, J.; COLLINS, M.; HASSOBA, H. M.; WRIGHT, T. L. Quantitation of hepatitis $G$ and $C$ viruses in the liver: Evidence that hepatitis $G$ virus is not hepatotropic. Hepatology, 27(3), p. 877-880, 1998.

PONZETTO, A.; FORZANI, B.; PARRAVICINI, P.P.; HELE, C.; ZANETTI, A. et al. Epidemiology of hepatitis delta virus infection. Eur J Epidemiol, 1, p. 257-263, 1985.

RESHETNYAK, V. I.; KARLOVICH, T. I.; ILCHENKO, L. U. Hepatitis G virus. World Journal of Gastroenterology, 14(30), 4725-4734. 2008

RIBEIRO, D. F.; CORREIA, B. R.; SOARES, A. K. F.; ROCHA, M. K. L.; ALVES, E. R. P.; ALBUQUERQUE, M. C. P. A. Educação em saúde: uma ferramenta para a prevenção e controle de parasitoses. Rev Univ Vale do Rio Verde, vol. 11, p. 300-310, 2014.

SOUTO, F. J.; FONTES, C. J.; MARTELLI, C. M.; TURCH, M. D.; MARTINS, R. M.; \& Ana Lúcia S Sgambatti De Andrade. Hepatitis $C$ virus prevalence among an immigrant 
community to the Southern Amazon, Brazil. Memórias do Instituto Oswaldo Cruz, vol. 94(6), p. 719-723, 1991.

TRATA BASIL, Situao Saneamento no Brasil. from <http://www.tratabrasil.org.br/saneamento-no-brasil>, Retrieved: April 25, 2017.

VIANA, S.; PARANá, R.; MOREIRA, R. C.; COMPRI, A. P.; MACEDO, V. High prevalence of hepatitis $B$ virus and hepatitis $D$ virus in the western Brazilian Amazon. Am J Trop Med Hyg, vol. 73, p. 808-814, 2005.

VITRAL, C. L.; SOUTO, F. J.; GASPAR, A. M. Changing epidemiology of hepatitis A in Brazil: reassessing immunization policy. Journal of Viral Hepatitis, vol. 15, p. 22-25, 2008.

VOS, T.; BARBER, R. M.; BELL, B.; BERTOZZI VILLA, A.;BIRYUKOV, S.; BOLLIGER, I.; CHARLSON, F.; DAVIS, A.; DEGENHARDT, L.; DICKER, D.; DUAN, L.; ERSKINE, H.; FEIGIN, V. L.; FERRARI, A. J.; FITZMAURICE, C.; FLEMING, T.; GRAETZ, N.; GUINOVART, C.; HAAGSMA, J.; HANSEN, G. M.; HANSON, S. W.; HEUTON, K. R.; HIGASHI, H.; KASSEBAUM, N.; KYU, H.; LAURIE, E.; LIANG, X.; LOFGREN, K.; LOZANO, R.; MACINTYRE, M. F. et al. Global, regional, and national incidence, prevalence, and years lived with disability for 310 diseases and injuries, 1990-2015: a systematic analysis for the Global Burden of Disease Study 2015. The Lancet, vol. 388, p. 1545-1602, 2016.

WHO. Factsheets - Hepatitis B, 2016. from <http://www.who.int/mediacentre/factsheets/fs204/en/>, Retrieved: April 11, 2017

WHO. Know hepatitis - Act now. (n.d.). from <http://www.who.int/hepatitis/en/>, Retrieved April 11, 2017.

WHO 10 YEAR REVIEW. Viral hepatitis: a hidden killer gains visibility, 2017. from $<$ http://www.who.int/publications/10-year-review/hepatitis/en>, Retrieved May 04, 2017.

WORLD BANK. Brazil: Water and Sanitation for Isolated Communities in the amazon, 2014. from <http://www.worldbank.org/en/news/press-release/2014/09/29/brazilwater-and-sanitation-for-isolated-communities-in-the-amazon>, Retrieved: May 05, 2017.

Recebido em 05/09/2018 Aceito em 01/10/2018 